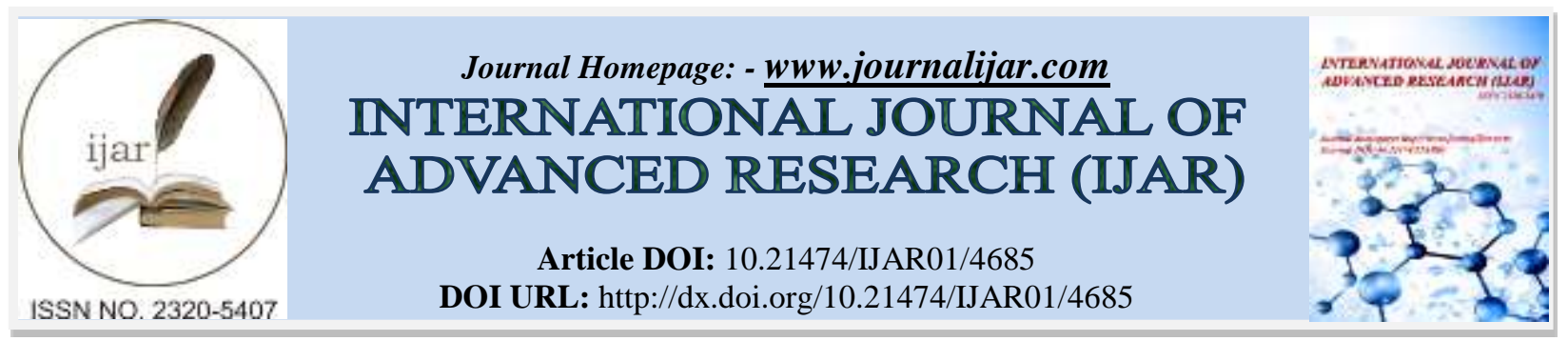

RESEARCH ARTICLE

\title{
IMPACT OF SHOPPER, STORE AND SITUATIONAL FACTORS ON SATISFACTION AND LOYALTY OF CUSTOMERS
}

\author{
Kulbir Kaur Bhatti ${ }^{1}$, Farhat Fatima ${ }^{3}$ and Deepanshu Mehta ${ }^{3}$. \\ 1. Assistant Professor, Periyar Management and Computer College, New Delhi - 110025, India. \\ 2. Student, Periyar Management and Computer College, New Delhi - 110025, India.
}

\section{Manuscript Info}

(..........................

Manuscript History

Received: 28 April 2017

Final Accepted: 30 May 2017

Published: June 2017

Key words:-

retail, brands, customers, strategies, marketers, loyalty

\section{Abstract}

The enormous retail boom in India has given opportunity to many companies who have mushroomed out to benefit from this retail growth, which is nothing but a structured format of the unorganized retail business which is being done in India from ages. Many stores have come up with exquisite interiors, state of the art infrastructure and the best possible brands to the customer which has led to the growth of mall culture in India. The stores try and attract customers by providing them with such services and plethora of options in brands in different categories so that they can retail customers for long and make them loyal towards their retail stores. The retail business is growing in India and there has been remarkable shift in the buying behavior of the people from traditional stores to these departmental stores. It becomes important for the marketers to understand these relationships for successful design and execution of retail strategies. This paper gives an insight to understand the organized retail formats and consumers buying attitude towards these stores. The data was collected through questionnaire filled by the respondents who were loyalty card holders to find out that what makes them loyal and motivates them to purchase more from XYZ stores. The purpose of this paper is to understand the relationship between the various factors and how they lead to store loyalty.

Copy Right, IJAR, 2017,. All rights reserved.

\section{Introduction:-}

Retailing consists of the sale of goods or merchandise from a fixed location, such as a department store, shopping mall etc .The retailer buys goods or products in large quantities from manufacturers either directly or through a wholesaler, and then sells smaller quantities to the end-user. Retail establishments are often called shops or stores. Retailers are at the end of the supply chain. Manufacturing marketers see the process of retailing as a necessary part of their overall distribution strategy. In the retail outlet various types of goods and service are provided to the customer but all the goods and services are generally homogenous in nature through all the other retail outlets. Product and services of every brand is available in the retail outlet. It is found that many customers already decide the outlet for shopping rather than shopping from every outlet even if there is homogenous product and service offered by the retail outlet. The customers have no identical likes and preferences. The retailer found that there is a gap between what customer expects and what retailer provides to customer during shopping. Delivering value and narrowing down the zone of tolerance is a tightrope walk for marketer in organized retail sector. Especially in 
market like India the challenges is formidable because organizations need to cater to a wide and diverse group of customers. Thus building equity and generating volumes in such complex market tapers down to the function of managing customer expectation. Customers take their time to first sketch their needs and then arrive at a specific decision. To fill the existing gap between the customer and retailer the choices of the customer must be given the highest priority. In this competitive scenario the customer is well informed, commanding and demanding so at the same time it has become imperative for the organization to be updated to meet the customer's requirements. This calls for empathizing with the customer by indulging into their priorities and decision making. Even in the case of a product as simple as beauty soap, customer have versatile expectations like, good packaging fragrance, herbal or medical benefit, glowing skin etc. and all this at an affordable price. A daunting task but companies have no option but to offer the expected value, that too by keeping the operating costs low. The general expectations of a typical customer are value of money, availability and location service expectations, quality and need based solution. Retail outlets in addition to providing products and services, need to cater for a wide range of motives. The various determinants of retail outlet preference include cleanliness, well-stocked shelves, range of products, helpful staff, disabled access, wide aisles, car parking, multiple billing points and environmentally friendly goods. These differing motives arise as retailers cater to different types of shoppers who include economic consumers (concern with value), personalized consumers (concern with relationships), recreational shoppers (shopping as a leisure activity) and apathetic consumers (who dislike shopping). Retailers have to satisfy budding customers, older consumers as well as time crunched individuals whose motives all tend to be conflicting as well as different. Retailers need to establish a good image to prevent customers from shopping around. They must cater to shoppers need for pleasure and practicality. The study would enable us to understand the impact of various factors that influence a consumer's shopping behavior in a departmental store. It would also help in knowing the magnitude and direction of movement of these factors amongst each other. These factors have been divided into three heads- Store, Situation and Shopper factors. The hurdles of the retail industry are that automatic approval is not allowed for foreign investment in retail, regulations restrict real estate purchases and cumbersome local laws, taxation favors small retail businesses,_absence of developed supply chain and integrated IT management, lack of trained work force,_low skill level for retailing management and finally intrinsic complexity of retailing - rapid price changes, constant threat of product obsolescence and low margins.

\section{Objective of the study:-}

1. To understand the several factors that influences the consumers to buy a product.

2. To understand the satisfaction level of the consumers.

\section{Literature Review:-}

Satisfaction is a consumer's post-purchase evaluation of the overall service experience. It is an affective reaction (Menon and Dubé, 2000) in which the consumer's needs, desires and expectations during the course of the service experience have been met or exceeded (Lovelock, 2001). Satisfaction in this sense could mean that a supermarket has just barely met the customer's expectations, not exceeded nor disappointed those expectations. The benefits of taking the customer's response beyond satisfaction at this level by exceeding expectations, is a competitive strategy many retailers aspire to achieve. A strong competitiveness is observed in both quantity and quality and it is extremely difficult for a firm to differentiate itself from its competitors. However dynamic business environments and increasing customer power have pushed firms toward a customer-focused strategy, especially using new technology to build relationships with the customer (Ryding, 2010). There is a recurrent struggle for existence and survival in the wake of deep competition, drastically changing customer attitudes and expectation levels. The concept of store loyalty is derived from the concept of brand loyalty which refers to the tendency to make repeat purchases of products of the same brand. Store loyalty refers to the tendency to repeatedly shop at the same store for similar or other products. A loyal customer would give preference to a specific store and would tend to be far more forgiving of errors of the store. There are three main set of variables that have been found to have an impact on loyalty of customers: Store Related Variables, shopper Related Variables, Situation Related Variables (Hubbard, Raymond 1978). The consumers are favorably inclined to revisit a store where they have positive shopping experiences like a great range of assortments, good environment etc. The image of the store has also great effect on the loyalty of the customers. Store image reflects shopper's perception of a store in terms of functional and psychological attributes (Arnold, et al 1983). Loyalty has been found to be greatly influenced by Store Related Variables. Some of the important store related variables are Shop location, Products Range and Store Image. In consumer priorities, assortment and variety come after convenience and price. Shop location is an influencing variable on loyalty as convenience of shopping is among the main criteria of the customers. Loyalty is also influenced by shopper related variables. Several factors such as age, income and social class of the shopper have 
found to influence on customer's decisions. Customers belonging to different age groups prefer different stores. There have been researches done which suggests that the greater the congruence between self image and store image, the greater is the probability that the customer is loyal. There is a direct linkage between personal values and desired consumer benefits. This means different customers have different levels of desired consumer benefits which vary according to their own perceived values. Loyalty is also influenced by the situation related variables. These factors include task definition, level of involvement, shopping orientation and usage of information. These indicate the intensity of need and the comfort of the shopper in taking a purchase decision. The store choice has been found to depend on buying situations that differ with the level of involvement (Moschis, G.P .1976). The employee loyalty, service quality, and customer satisfaction have a positive influence on customer loyalty in a high-contact service industry (Yee, Yeung, and Cheng, 2010). Loyalty can be developed through different phases, which are cognitive sense, affective sense, conative manner, and finally behavioural manner. The first three phases are usually referred as attitudinal loyalty which are dependent on the experiences that customers have with service providers (overall satisfaction) that leads to the behavioral loyalty as the final stage (Oliver, 1999).

\section{Consumer Pull Factors:-}

$>$ A critical factor in XYZ's success has been its strategy to attract shoppers \& keep them in stores- the amount of time shoppers spend in a store is perhaps the single most important factor in determining how much they will buy. . In having understood the pulse of the customers in India, XYZ has clearly established itself as a brand with an Indian heart.

$>$ Over the years XYZ has also developed and successfully introduced a range of new brands especially suited to the Indian palate. These brands like Sassy soda, Wonder Love have been a tremendous success amongst the new generation. What has also given XYZ a competitive edge is that in addition to an extensive range of internationally renowned brands like Spykar, Lee and Fast Track they also offer the option of a less known brands for low budget customers.

$>$ All the three floors are carefully structured. Ground floor and Ist floor caters exclusively to Women and IInd floor to Men respectively. Thus giving them privacy and more freedom to look into their products.

$>$ Women's need more space and look for comfort. They are less likely to buy if the place is congested and makes them feel uncomfortable. At XYZ sofas have been placed in the women section so as to make the females more comfortable.

$>\mathrm{XYZ}$ has been able to create a brand image and is consistently maintaining its brand identity by new additions in products and catering to the market need.

$>$ They are catering to different age groups under one roof. For ex. On the IInd floor which is men's section both formal and college wear is available. This way they are able to build a huge customer loyal base.

$>\mathrm{XYZ}$ caters to not only the clothing needs and desires of its customers. They have bed sheets, kitchenware, jewellery, perfumes, baby products, household items, etc. This way a customer who enters XYZ just to buy one or two items usually ends up buying a lot more.

$>$ The in-store experience in XYZ is very delightful. Their fully skilled and trained staff caters to the needs of the public in the right way. They don't pounce upon the customer as soon as he enters the store. They wait till the time a customer starts selecting and then they come and help. This way the customer gets acclimatize with the store and the environment.

$>$ Price of brands available at XYZ is not too high as compared to its competitor's brands. This is due to their cost effective supply chain management. They directly pick up the goods from the manufacturer thus ensuring low price tag at their store.

\section{Research Methodology:-}

The data was collected through primary source through questionnaires, interviews, observations etc. coming to XYZ while exiting point-of-sale venues. The study provides a representative sample of the main Shopping centre in Delhi. In order to reckon with possible multi-loyalty, questions related to satisfaction, loyalty and behavior were asked for the regular main store visited (at least once a week). The sample would be surveyed on the basis of questionnaire and data would be quantified for further analysis

\section{Data Analysis:-}

Price of the Items:-

$44 \%$ of respondents are satisfied with the price of items which are available in the retail stores. Only a few customers are dissatisfied with the price of the products and services and move to the other stores.

\section{Store Ambience:-}


$52 \%$ respondents are satisfied with the store ambience. The store manipulates their environment to create a atmosphere which meets the expectations and choice of the customer. The customer who are satisfied have commented that they are satisfied by the music played, the clientele, lighting and, most importantly, the retail service, is projection of the store's corporate image. The customers feel inclined towards the store when they enter the retail store.

\section{Ease of Availaibilty:-}

$40 \%$ respondents are saying that they easily get the stock. Products with stationary demand tend to have a relatively constant monthly sale, which greatly simplify forecasting and reduces the number of possible errors. Availability of the products is higher in larger retail formats is due to product availability in better space allocation possibilities for both products with high and lower turnover.

\section{Sales Promotion Offers:-}

$43 \%$ respondents like the sales promotion activities of XYZ. They offer discounts such as Price Discounts (reward program, cents-off deal,), Coupons (, on-shelf couponing, on-line couponing, mobile couponing) Games and Events (Online interactive promotions, contests, games).

\section{Ambience would be an important factor:-}

$27 \%$ respondents strongly approve that ambience is an important factor. The store owners often manipulate their environment to create a desired atmosphere. The social atmosphere defined in terms of the music played, the clientele, most importantly the retail service, is a projection of the store's corporate image. The ambience plays an important role as to whether patrons will feel inclined to step into the store, stay or leave immediately.

\section{Convenience would be given special Attention:-}

$34 \%$ strongly approve that convenience would be given special attention. Customers have convenience when they can shop fast with ease. The retailers who offer convenience focus on reach, search convenience to identify and select the required products, to obtain the products which are the possession convenience and the purchase and return of products is the transaction convenience.

\section{Word of Mouth is important:-}

$48 \%$ respondents are moderate who think that word of mouth is important. Word of mouth is one of the most powerful drivers of traffic and sales for retailers. Word of mouth marketing is a tactic used to generate natural discussions about and recommendations for a product or company. Essentially, getting people to talk about your brand, product, or business is the goal of this type of marketing. Many of your customers will talk about the store to others when they are fully satisfied by the product and retail services.

\section{Quality of Product:-}

$52 \%$ respondents are satisfied with the product. The importance of quality may be understood at the time of consumption, even the quality of packing plays a very important role in getting the products go off the shelf. The quality tests become even more stringent in as the needs of the consumers are increasing. A lot of organizations these days try to implement and follow Quality Control Systems (QCSs) to ensure that the quality criteria of products are met. This may include tasks like inspecting raw materials for quality, checking the external variables as weights and temperature etc., and then performing a final inspection of the product.

\section{Variety of Product:-}

$56 \%$ respondents are satisfied with the variety of product. It refers to the breadth and depth of the products a given retail store carries on a regular basis. If a store stocks too much of a variety of merchandise, it may lack focus, which could confuse customers. On the other hand, if a merchandise mix is too small or limited; the store runs the risk of being overshadowed by better-stocked competitors. A proper analysis of the inventory status, price-point analysis, square-inch analysis, and category analysis and gross-margin percentage should be done to stock the mer4chandise mix. 


\section{Visual Merchandising of Store:-}

$34 \%$ respondents strongly agree that they like the visual merchandising of store. Visual merchandising is a multisensory tool used by retailers to catch the attention of customers and attract them into a store to make a purchase. The first piece of visual merchandising customers encounter with a brand is the window display. It makes the product easier to locate, moves the product faster and the product is self explanatory and a good experience for the buyers.

\section{Conclusion:-}

The customers are satisfied with existing quality and variety of XYZ apparels. The users are loyal towards the products. The positive word of mouth and price of items, store ambience make the customers rebuy from the same store. Customers prefer the XYZ products because it provides good quality, good results, good services, etc and it all fulfills their needs.To increase more footfalls more promotional activities must be carried out. For this XYZ can either offer more discounts or increase their advertisements. Increase in the number of footfalls will lead to increase in sales. Since XYZ is not only catering to apparel need of the society a few additions like Books, Music items, Electronic gadgets etc can also be added to the products available inside their store. The demand for the above products is always in the market. Allowing more space between the entrance of a store and a product gives it more time in the shopper's eye as he or she approaches it. It builds a little visual anticipation. The number of trial rooms available at XYZ is very less as compared to the number of people coming. This usually results in long queues and waiting by customers. Install more full length mirrors inside the store so as to assist the customers to make better purchase decisions. Play light music inside the store to make the shopping a pleasurable experience._They can also exhibit their new line of clothing through events like fashion shows._Baskets should be scattered throughout the store, wherever shoppers might need them. Many customers don't begin seriously considering merchandise until they have browsed a bit.

\section{References:-}

1. Arnold, Lande, "The Measurement of Selection on Correlated Characters," Evolution, Vol 36, 1983

2. Hubbard, Raymond, "A Review of Selected Factors Conditioning Consumer Travel Behavior," Journal of Consumer Research, 5 (July 1978), 1-21.

3. Laurette Dubé, Kalyani Menon, (2000) "Multiple roles of consumption emotions in post-purchase satisfaction with extended service transactions", International Journal of Service Industry Management, Vol. 11 Issue: 3, pp.287-304, https://doi.org/10.1108/09564230010340788

4. Lovelock, C.H., Patterson, P.G. and R.H. Walker, Services Marketing: An Asia-Pacific Perspective, 2ndedn, 2001, Prentice Hall, NSW

5. Moschis, G. P. (1976). Acquisition of the Consumer Role by Adolescents. University of Wisconsin, Madison.

6. Oliver, R. L. (1999). Whence Consumer Loyalty? Journal of Marketing, 63, 33. doi:10.2307/1252099

7. Ryding, D. (2010). The impact of new technologies on customer satisfaction and business to business customer relationships: Evidence from the soft drinks industry. Journal of Retailing and Consumer Services, 17(3), 224228. doi:10.1016/j.jretconser.2010.03.008

8. Yee, R. W. Y., Yeung, A. C. L., \& Edwin Cheng, T. C. (2010). An empirical study of employee loyalty, service quality and firm performance in the service industry. International Journal of Production Economics, 124(1), 109-120. doi:10.1016/j.ijpe.2009.10.015 